\title{
PENINGKATAN KINERJA MELALUI DISIPLIN, MOTIVASI DAN LINGKUNGAN KERJA PADA SATUAN RESKRIM
}

\author{
10.34005/akademika.v8i02.324
}

\author{
Dewi Puspita \\ deepuspita88@gmail.com \\ Universitas Mercubuana Jakarta-Indonesia
}

\author{
Tjiptogoro Dinarjo Soehari \\ tjiptogd@yahoo.com \\ Universitas Mercubuana Jakarta-Indonesia
}

\begin{abstract}
This study aims to find a model for building Police Officer' at Satuan Reskrim Polres Metro Bekasi Kota to perform optimally. The method used in this study is explanatory research and SPSS software for Windows version 24. The population in this study was 94 Police Officer' at Satuan Reskrim Polres Metro Bekasi Kota by using saturated sampling method. Data Variable collected by distributing questionnaires. The number of respondents who returned questionnaire as many as 94 . Variable their lack of roots is a an employee $(Y)$. Variabels free are discipline ( $X 1$ ), motivation ( $X 2$ ) and work environment ( $X 3$ ), while Equation of Multiple Linear Regression $Y=-1,561+0,0,547 \times 1+0,487 \times 2+0,278 \times 3+e$; Rsquare $=0,670, F=60,893$, Discipline is the most dominant factor in employee performance. discipline, motivation and work environment have a positive and significant influence on employee performance. The results of employee performance are $-1,561$, If $X 1$, $X 2$, and $X 3$, are considered zero, it will affect employee performance of $-1,561$ if the 1-5 Likert scale is included in the not too good category.
\end{abstract}

Keywords : Discipline, Motivation and Work Environment

\begin{abstract}
Abstrak : Penelitian ini bertujuan mencari model untuk membangun personil Satuan Reskrim Polres Metro Bekasi Kota agar berkinerja secara optimal.Metodologi yang digunakan dalam penelitian ini adalah metode kuantitatif eksploratif dan software SPSS for Windows versi 24.Populasi meliputi 94 responden personil Satuan Reskrim Polres Metro Bekasi Kota dengan menggunakan sampel jenuh. Variabel terikat adalah kinerja personil ( $Y$ ), sedangkan variabel bebas yaitu disiplin (X1), Motivasi(X2) dan Lingkungan Kerja (X3). Hasil penelitian: (1) Persamaan regresi linear berganda $Y=-1,561+0,0,547 \times 1+0,487 \times 2+0,278 \times 3+e$; Rsquare $=0,670, F=60,893$; (2) Disiplin menjadi faktor paling dominan terhadap Kinerja; (3) disiplin, motivasi dan lingkungan kerja berpengaruh positif dan signifikan terhadapkinerja.Keterbaruan yang di temukan adalah Hasil dari kinerja karyawan adalah sebesar -1,561, Apabila X1,X2dan X3 dianggap nol, maka akan mempengaruhi kinerja karawan sebesar -1,561 jika dalam skala likert 1-5 termasuk dalam katagori sangat tidak baik.
\end{abstract}

Kata Kunci : Disiplin, Motivasi dan Lingkungan Kerja. 


\section{PENDAHULUAN}

Sumber daya manusia dalam hal ini adalah personil Satuan Reskrim Polres Metro Bekasi Kota menjadi sentral dalam pencapaian tujuan organisasi. Sumber daya manusia dalam setiap organisasi baik publik maupun bisnis adalah sumber daya yang utama dikarenakan manusia menjadi pelaku utama yang menggerakkan berbagai sumber daya yang dimiliki oleh sebuah organisasi. Di dalam pencapaian tujuan dari setiap organisasi sangat diperlukan sumber daya manusia yang berkinerja baik karena faktor sumber daya manusia memiliki peranan yang sangat vital dan harus dikelola dengan baik sehingga membawa manfaat bagi organisasi. Oleh karena itu, sebuah organisasi tidak mungkin dapat mencapai visi, misi dan tujuannya apabila sumber daya manusia tidak memiliki kinerja yang baik.

Kepolisian Republik Indonesia (Polri) adalah alat negara yang mempunyai tugas pokok untuk memelihara keamanan dan ketertiban masyarakat, menegakkan hukum, serta memberikan perlindungan, pengayoman, dan pelayanan kepada masyarakat dalam rangka terpeliharanya keamanan dalam negeri. Di dalam melaksanakan tugas pokoknya, organisasi Polri disusun secara berjenjang dari tingkat pusat sampai ke kewilayahan.

Organisasi Polri tingkat pusat disebut Markas Besar Kepolisian Republik Indonesia (Mabes Polri), sedangkan organisasi Polri tingkat kewilayahan disebut Kepolisian Negara Republik Indonesia Daerah (Polda) di tingkat provinsi, Kepolisian Negara Republik Indonesia Resort (Polres) di tingkat kabupaten/kota, dan Kepolisian Negara Republik Indonesia Sektor (Polsek) di wilayah kecamatan. Untuk tingkat Polres membawahi Polsek. Untuk kotakota besar, Polres dinamai Polrestabes. Polres memiliki satuan tugas kepolisian yang lengkap, layaknya Polda.

Satuan Reserse Kriminal (Reskrim) merupakan unsur pelaksana tugas pokok yang berada di bawah Kapolres. Satuan Reskrim bertugas melaksanakan penyelidikan, penyidikan dan pengawasan penyidikan tindak pidana, termasuk Identifikasi dan Laboratorium Forensik lapangan serta pembinaan, koordinasi dan pengawasan PPNS. Satuan Reskrim Polres Metro Bekasi Kota dipimpin oleh Kasat Reskrim yang bertanggung jawab kepada Kapolres dan dalam pelaksanaan tugas sehari-sehari di bawah kendali Wakapolres.

Di dalam pelaksanaan tugasnya, Satuan Reskrim menyelenggarakan fungsi pembinaan teknis terhadap administrasi penyelidikan dan penyidikan serta identifikasi dan laboratorium forensik lapangan, memberikan layanan dan pelindungan khusus kepada remaja, anak dan wanita sebagai pelaku maupun korban sesuai dengan ketentuan peraturan perundang-undangan, melakukan pengidentifikasian untuk kepentingan penyidikan dan pelayanan 
umum, melakukan penganalisisan kasus beserta penanganannya serta mengkaji efektivitas pelaksanaan tugas Satuan Reskrim, melaksanakan pengawasan penyidikan tindak pidana yang dilakukan oleh penyidik pada unit Reskrim Polsek dan Satuan Reskrim Polres, melakukan pembinaan, koordinasi dan pengawasan PPNS baik di bidang operasional maupun administrasi penyidikan sesuai dengan ketentuan peraturan perundangundangan, serta melaksanakan penyelidikan dan penyidikan tindak pidana umum dan khusus antara lain tindak pidana ekonomi, korupsi dan tindak pidana tertentu di daerah hukum Polres.

Berdasarkan data dari Polres Metro Bekasi Kota, data penyelesaian laporan Polisi di Satuan Reskrim pada tahun 2014 - 2017 terjadi trend penurunan dengan rata-rata persentase penyelesaian laporan sebesar $47,51 \%$ dengan kategori cukup, sehingga berpengaruh terhadap penilaian kinerja Satuan Reskrim Polres Metro Bekasi Kota pada pelaksanaan pelayanan dan program kerja yang telah direncanakan.

Untuk mengetahui penilaian kinerja personil di Satuan Reskrim Polres Metro Bekasi Kota yang belum optimal maka digunakan model faktor-faktor yang mempengaruhi kinerja pegawai, adapun faktor-faktor yang mempengaruhi kinerja individu dipengaruhi oleh faktor intrinsik yaitu faktor yang berasal dari individu sendiri dan faktor ekstrinsik yaitu faktor dari luar individu yang bersangkutan. Faktor intrinsik meliputi komunikasi, motivasi kerja, dan disiplin kerja sedangkan faktor ekstrinsik meliputi pendidikan dan pelatihan, tunjangan kinerja, gaya kepemimpinan, teknologi informasi, budaya organisasi, lingkungan kerja dan pengembangan karir.

Untuk mengerucutkan faktor - faktor yang mempengaruhi kinerja personil dilakukan wawancaraterhadap 6 (enam) orang responden ahli yakni responden merupakan orang yang menangani pembinaan secara langsung kepada personil dan responden yang menduduki jabatan tertentu di Satuan Reskrim dan mendapatkan hasil 5 (lima) faktor yang mempengaruhi kinerja yaitu lingkungan kerja, disiplin, pengembangan karir, tunjangan kinerja dan motivasi. Selanjutnya, mengerucutkan menjadi 3 (tiga) faktor yang mempengaruhi kinerja personil menurun dengan melakukan wawancara berupa kuesioner kepada 15 (lima belas) responden dengan mempertimbangkan faktor demografinya, yaitu jabatan, jenis kelamin, dan tingkat pendidikan terakhir. Berdasarkan analisis hasil prastudi, maka peneliti memperoleh 3 (tiga) faktor yang diduga paling berpengaruh terhadap kinerja, yaitu disiplin kerja, motivasi kerja dan lingkungan kerja.

Disiplin dalam penelitian ini adalah mengacu pada anggota Kepolisian Negara Republik Indonesia, khususnya pada anggota Satuan Reskrim Polres Metro Bekasi Kota. Dalam hal ini, Polri sebagai sub sistem dari pemerintah secara responsif telah berupaya memberi kontribusi mewujudkan good governance dan clean government, baik dalam pelaksanaan tugas pokok untuk memelihara Kamtibmas, menegakkan hukum dan melindungi, 
mengayomi serta melayani masyarakat maupun di kalangan internal Polri sendiri sebagaimana dicanangkan dalam grand strategy Polri berupa membangun kepercayaan atau trust building (Dwiyanto,2014:3).

Kondisi melemahnya disiplin dan profesionalisme anggota Polri yang terjadi pada saat ini sering menjadi pembicaraan masyarakat luas. Dengan seiring diberitakannya di berbagai media massa mengenai tindakan indisipliner yang dilakukan oleh anggota Polri, misalnya banyaknya kasus penyalahgunaan senjata api oleh anggota Polri, adanya anggota Polri yang terlibat dalam tindak pidana, tindakan sewenang-wenang anggota Polri, dan masih banyak kasus lain yang menggambatkan kurangnya disiplin anggota Polri, menjadikan keprihatinan sendiri bagi masyarakat terkait dengan pelaksanaan tugas pokok Polri yaitu menjaga keamanan dan ketertiban masyarakat, tertib dan tegaknya hukum, terselenggaranya perlindungan, pengayoman, dan pelayanan kepada masyarakat, serta terbinanya ketentraman masyarakat dengan menjunjung tinggi hak asasi manusia (Kadarmanta, 2014:23). Penyimpangan perilaku anggota Polri tersebut di atas adalah merupakan pelanggaran terhadap peraturan disiplin anggota Polri sebagaimana yang diatur dalam Peraturan Pemerintah Republik Indonesia Nomor 2 Tahun 2003 tentang Peraturan Disiplin Anggota Polri.

Pengertian disiplin adalah kehormatan, kehormatan erat kaitannya dengan kredibilitas dan komitmen. Disiplin anggota Kepolisian adalah kehormatan yang menunjukkan kredibilitas dan komitmen yang teguh. Kredibilitas dan komitmen anggota Polri adalah sebagai pejabat negara yang diberikan tugas dan kewenangan selaku pelindung, pengayom, dan pelayanan masyarakat serta sebagai penegak hukum dan pemeliharaan keamanan. Komitmen berbeda dengan loyalitas karena loyalitas cenderung mengarah pada sifat mutlak dan berujung pada kecenderungan pemimpin untuk menggunakan loyalitas tersebut. Penegakan disiplin anggota Kepolisian didasarkan pada kesadaran daripada rasa takut, dan didasarkan pada komitmen serta loyalitas. Peraturan disiplin bagi anggota Polri disamping mengatur tata kehidupan dan tugas juga mengatur kehidupan anggota Polri selaku pribadi dalam kehidupan masyarakat. Untuk membina persatuan dan kesatuan serta meningkatkan semangat kerja dan moril diadakan peraturan disiplin bagi Anggota Kepolisian Negara Republik Indonesia (Rahardi, 2013:124).

Pendapat lain merumuskan disiplin kerja menurut Hasibuan (2012:193) adalah kesadaran dan kesediaan seseorang menaati semua peraturan dan norma-norma sosial yang berlaku. Kesadaran adalah sikap seseorang yang secara sukarela menaati semua peratuan dan sadar akan tugas dan tanggung jawabnya, kesediaan adalah suatu sikap, tingkah laku, dan peraturan organisasi, baik yang tertulis maupun tidak.

Motivasi menurut G. R Terry dalam Siagian (2014:145) dikatakan sebagai keinginan yang terdapat pada diri seseorang individu yang 
merangsangnya untuk melakukan tindakan-tindakan. Motivasi itu tampak dalam dua segi yang berbeda, yaitu dilihat dari segi aktif/dinamis, motivasi tampak sebagai suatu usaha proaktif dalam menggerakkan, mengerahkan dan mengarahkan daya serta potensi tenaga kerja, agar secara produktif berhasil mencapai dan mewujudkan tujuan yang ditetapkan sebelumnya. Sedangkan apabila dilihat dari segi pasif/statis, motivasi akan tampak sebagai kebutuhan sekaligus sebagai perangsang untuk dapat menggerakkan, mengerahkan, dan mengarahkan potensi serta daya kerja manusia tersebut ke arah yang diinginkan.

Motivasi dikatakan oleh Azwar (2012:15) adalah rangsangan, dorongan ataupun pembangkit tenaga yang dimiliki seseorang atau kelompok masyarakat yang mau berbuat dan bekerjasama secara optimal dalam melaksanakan sesuatu yang telah direncanakan untuk mencapai tujuan yang telah ditetapkan. Teori motivasi yang dikembangkan oleh Herzberg dalam Pasolong (2013:107) dikatakan motivasi merupakan faktor yang mempengaruhi kondisi pekerjaan seseorang, yaitu faktor pemuas (motivation factor) yang disebut juga dengan satisfier atau intrinsic motivation dan faktor kesehatan (hygienies) yang juga disebut sebagai disatisfier atau extrinsic motivation. Teori ini melihat ada dua faktor yang mendorong pegawi termotivasi, yaitu faktor intrinsik meliputi daya dorong yang timbul dari dalam diri masing-masing orang, dan faktor ekstrinsik meliputi daya dorong yang datang dari luar diri seseorang, terutama dari organisasi tempatnya bekerja.Hasibuan (2013:146) mengemukakan:

Beberapa tujuan yang dapat diperoleh dari pemberian motivasi, yaitu: 1) Meningkatkan moral dan kepuasan kerja pegawai; 2) Meningkatkan prestasi kerja pegawai; 3) Meningkatkan kedisiplinan pegawai; 4) Mempertahankan kestabilan organisasi/perusahaan; 5) Mengefektifkan pengadaan pegawai; 6) Menciptakan suasana dan hubungan kerja yang baik; 7) Meningkatkan loyalitas, kreativitas dan partisipasi; 8) Meningkatkan tingkat kesejahteraan pegawai; 9) Meningkatkan rasa tanggung jawab pegawai terhadap tugas; 10) Meningkatkan efisiensi penggunaan alat-alat dan bahan baku.

Lingkungan kerja didefinisikan oleh Sedarmayanti (2013:21) sebagai keseluruhan alat perkakas dan bahan yang dihadapi, lingkungan sekitarnya dimana seseorang bekerja, metode kerjanya, serta pengaturan kerjanya baik sebagai perseorangan maupun sebagai kelompok. Lebih lanjut, Sedarmayanti (2013:31) membagi lingkungan kerja menjadi lingkungan fisik dan nonfisik yang melekat pada pegawai sehingga tidak dapat dipisahkan untuk mendapatkan kinerja pegawai yang baik. Lingkungan kerja fisik adalah semua keadaan berbentuk fiisk yang terdapat di sekitar tempat kerja yang dapat mempengaruhi pegawai baik secara langsung maupun secara tidak langsung. Sedangkan lingkungan kerja nonfisik adalah semua keadaan yang terjadi berkaitan dengan hubungan kerja, baik hubungan dengan atasan maupun dengan rekan kerja, ataupun hubungan dengan bawahan. 
Menurut Schultz \& Schultz dalam Nitisemito (2012:45) lingkungan kerja diartikan sebagai suatu kondisi yang berkaitan dengan ciri-ciri tempat bekerja terhdap perilaku dan sikap pegawai dimana hal tersebut berhubungan dengan terjadinya perubahan-perubahan psikologis karena hal-hal yang dialami dalam pekerjaannya atau dalam keadaan tertentu yang harus terus diperhatikan oleh organisasi yang mencakup kebosanan kerja, pekerjaan yang monoton dan kelelahan.

Kinerja adalah pelaksanaan suatu pekerjaan dan penyempurnaan pekerjaan tersebut sesuai dengan tanggung jawabnya sehingga dapat mencapai hasil sesuai dengan yang diharapkan. Definisi ini lebih menunjukkan bahwa kinerja lebih ditekankan pada proses, di mana selama pelaksanaannya dilakukan penyempurnaan-penyempurnaan sehingga pencapaian hasil pekerjaan atau kinerja dapat dioptimalkan. Stephen Robbins mendefinisikan kinerja sebagai hasil evaluasi terhadap pekerjaan yang dilakukan individu dibandingkan dengan kriteria yang telah ditetapkan (Sinambela, 2016:480).

Prawirosentono (2013:2) mengatakan kinerja adalah hasil kerja yang dpat dicapai oleh seseorang atau sekelompok orang dalam suatu organisasi, sesuai dengan wewenang dan tanggung jawab masing-masing, dalam rangka upaya mencapai tujuan organisasi bersangkutan secara legal, tidak melanggar hukum dan sesuai dengan moral dan etika.

Kinerja pegawai menurut Sinambela (2012:519) adalah kemampuan pegawai dalam melakukan sesuatu keahlian tertentu. Kinerja pegawai sangatlah perlu, sebab dengan kinerja ini akan diketahui seberapa jauh kemampuan mereka dalam melaksanakan tugas yang dibebankan kepadanya.

Dari ketiga teori tersebut persamaannya adalah kinerja merupakan hasil kerja individu dari keahlian yang dimiliki dalam menyelesaikan tugas dan beban kerja yang telah ditentukan oleh organisasi. Perbedaannya adalah wewenang dan tanggung jawab kinerja pada tiap pegawai berbeda-beda sesuai dengan kewenangan pada setiap pegawai. Jadi dapat disimpulkan bahwa kinerja adalah kemampuan yang dimiliki oleh individu dalam melakukan keahlian pekerjaan tertentu untuk dapat menyelesaikan tugas dan mencapai tujuan yang telah ditetapkan organisasi.

\section{METODE}

Pada penelitian ini penulis menggunakan pendekatan survey. Jenis penelitian ini adalah deskriptif kuantitatif. Variabel dalam penelitian ini adalah kinerja sebagai variabel dependen $(Y)$ sedangkan variabel independen $(X)$ adalah disiplin $\left(\mathrm{X}_{1}\right)$, motivasi $\left(\mathrm{X}_{2}\right)$ dan lingkungan kerja $\left(\mathrm{X}_{3}\right)$.

Populasi dalam penelitian ini adalah karyawan yang berjumlah 94 orang metode penarikan sampel dalam penelitian ini menggunakan sampel jenuh 
atau "sensus" yaitu keseluruhan populasi dijadikan sebagai sampel penelitian. Alat ukur penelitian yang digunakan berbentuk kuesioner. Analisis menggunakan teknik Analisis Regresi Linier Berganda dengan alat bantu SPSS (Statistical Product and Service Solution) versi 24.

\section{HASIL DAN PEMBAHASAN}

Dari hasil penelitian sebagian besar personil Satuan Reskrim Polres Metro Bekasi Kota berjenis kelamin pria dengan persentase $89,4 \%$ dan berjenis kelamin wanita dengan persentase 10,6\%. Berdasarkan latar belakang pendidikan personil yang menempuh pendidikan dengan persentese tertinggi adalah SLTA sebesar 53,2\%, diikuti S1 sebesar $40,4 \%$, S2sebesar 5,3\% dan yang terendah adalah DIII dengan nilai persentase $1,1 \%$.Dari sisi pengalaman kerja, personil yang memiliki masa kerja 1- 10 tahun sebesar 20,2\%, 11 - 19 tahun sebesar 39,4\%, 20-29 tahun sebesar $33 \%, 30$ - 39 tahun sebesar 7,4\%.

Uji validitas digunakan untuk mengukur valid tidaknya alat ukur yang digunakan, dengan kireteria penilaian uji validitas adalah jika $r$ hitung $>r$ tabel $=0,30$ maka dikatakan valid dengan $\alpha=0,05$. Penelitian ini memiliki instrumen pernyataan sebanyak 50 butir baik variebel terikat dan bebas, dengan menggunakan sampel sebanyak 30 responden, dari 50 pernyataan semuanya valid karena $r$ hitung $>0,30$.

Uji ini menggunakan Alpha Cronbach's, suatu variabel dikatakan reliabel jika a Cronbach $>0,6$, dari instrumen keempat variabel didapatkan hasil disiplin (X1) sebesar 0,831, motivasi (X2) sebesar 0,841, lingkungan kerja (X3) sebesar 0,856, dan Kinerja Karyawan (Y) sebesar 0,875 artian semuanya dinyatakan reliabel karena memiliki nilai a Cronbach lebih besar dari 0,60 maka keempat variabel tersebut memenuhi syarat reliabel sehingga dapat digunakan pada kuesioner penelitian dan pengumpulan data penelitian.

Dengan melakukan uji menggunakan histogram menunjukan bahwa kurvanya normal dikarenakan kurva yang berbentuk/ menyerupai lonceng, sedangkan menggunakan uji Normal P-Plot menunjukan bahwa data-data yang digunakan berada di sekitar garis normal (diagonal) tersebut dan terakhir peneliti melakukan uji normalitas dengan menggunakan Statistic nonparametric Kolmogorov-Smirnov yang mana hasil significance untuk variabel disiplin sebesar 0,094, motivasi sebesar 0,087, lingkungan kerja sebesar 0,200 dan variabel kinerja personil sebesar 0.115. Dari hasil tersebut dapat dilihat bahwa setiap siginifikansisemua variabel berada di atas $>0,05$, maka berdasarkan uji diatas dapat disimpulkan bahwa data yang digunakan oleh peneliti ini berdistribusi normal.

Mendeteksi ada tidaknya gejala multikolinearitas antar variabel independen dengan menggunakan nilai Tolerence dan Variance Inflation Factor (VIF), jika nilai Tolerance $>0,10$ dan nilai VIF $<10$ maka tidak terjadi multikolinieritas. Dari data hasil uji, nilai Tolerance dan VIF disiplin sebesar 
0,699 dan 1,431, nilai Tolerance dan VIF motivasi sebesar 0,724 dan 1,382, dan nilai Tolerance dan VIF lingkungan kerja sebesar 0,650 dan 1,538). Oleh karena ketiga variabel bebas memiliki nilai Tolerance di atas 0,10 dan nilai VIF di bawah 10, maka ketiga variabel bebas tidak mengalami gejala multikolinearitas.

Hasil dari scatterplot dapat dilihat bahwa data tidak membentuk suatu pola tertentu dan titik-titik data tidak hanya mengumpul di atas atau di bawah angka 0 saja melainkan menyebar di atas dan di bawah. Jadi, dapat disimpulkan bahwa tidak ada problem heterokedastisitas pada data residual.

Uji Regresi Linier Berganda

Tabel 1. Hasil Uji Regresi Linier Berganda

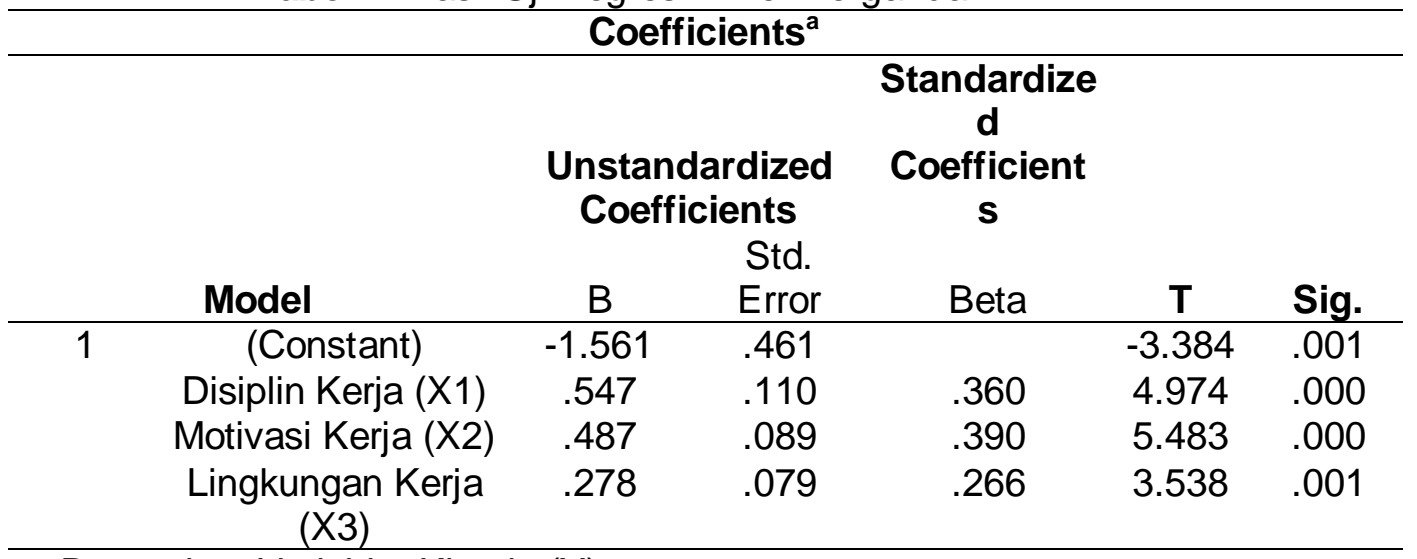

a. Dependent Variable: Kinerja $(\mathrm{Y})$

Sumber : Data diolah dengan SPSS Versi 24.0 (2018)

Berikut Penjelasan persamaan regresi yang diperoleh dari tabel 1 di atas sebagai berikut : 1) $\hat{Y}=-1,561+0,547 X_{1}+0,487 X_{2}+0,278 X_{3}+e$, 2) Angka koefisien regresi untuk variabel disiplin (X1) sebesar 0,547. Menyatakan bahwa apabila Variabel X2 dan X3 diangap nol (tidak dijalankan), maka variabel disiplin (X1) akan mempengaruhi kinerja personil $(Y)$ sebesar 0,547 . 3) Angka koefisien regresi untuk variabel Motivasi (X2) sebesar 0,487. Menyatakan bahwa apabila Variabel X1 dan X3 diangap nol (tidak dijalankan), maka variabel Motivasi (X2) akan mempengaruhi kinerja personil (Y) sebesar 0,487. 4) Angka koefisien regresi untuk variabel Lingkunga Kerja (X3) sebesar 0,278. Menyatakan bahwa apabila Variabel X1 dan X2 diangap nol (tidak dijalankan), maka variabel Lingkungan Kerja (X1) akan mempengaruhi kinerja personil $(\mathrm{Y})$ sebesar 0,278.

Adapun uji t secara parsial disiplin memiliki hubungan positif dan signifikan terhadap kinerja personil dengan hasil uji $t=4,974>$ dari nilai tabel $\mathrm{t}$ yaitu $=1,986$ dan tingkat signifikansi $0,000<$ dari 0,05 , variabel motivasi memiliki hubungan positif dan signifikan terhadap kinerja personil dengan 
hasil uji $\mathrm{t}=5,489>$ dari nilai tabel $\mathrm{t}$ yaitu $=1,986$ dan tingkat signifikansi $0,000<$ dari 0,05 , variabel lingkungan kerja memiliki hubungan positif dan signifikan terhadap kinerja personil dengan hasil uji $t=3,538>$ dari nilai tabel t yaitu $=1,986$ dan tingkat signifikansi $0,001<$ dari 0,05 .

Adapun uji $F$ Dari hasil Uji Anova nilai $F$ terlihat bahwa $F$ hitung $>F$ tabel $(60,893>2,706)$. Keputusan yang diambil berdasarkan hal tersebut adalah $\mathrm{Ho}$ ditolak, $\mathrm{Ha}$ diterima, sehingga dapat disimpulan bahwa disiplin (X1), motivasi (X2) dan lingkungan kerja (X3) berpengaruh secara signifikan terhadap kinerja personil $(Y)$ secara bersama-sama (simultan).

Dengan melakukan pengujian koefisien determinasi terlihat bahwa nilai $r$ square adalah 0,670 , hal ini berarti $67,0 \%$ kinerja personil dipengaruhi oleh disiplin kerja, motivasi kerja, dan lingkungan kerjasecara bersama-sama, sedangkan sisanya $33,0 \%$ dipengaruhi oleh variabel-variabel lainnya diluar variabel independen yang diteliti dalam penelitian ini.

\section{PEMBAHASAN}

1. Nilai kostanta sebesar $-1,561$, artinya apabila tidak ada kebijakan terkait disiplin (X1), motivasi (X2), dan lingkungan kerja (X3) maka hasil skor kinerja personil $(Y)$ sebesar-1,561, artinya kinerjanyanya termasuk dalam katagori sangat buruk jika mengacu dalam sekala likert 1-5, maka organisasi harus menjalankan 3 kebijakan seperti disiplin, motivasi dan lingkungan kerja.

2. Dari persamaan regresi terlihat bahwa nilaiyang terbesar adalah disiplin dengan skor sebesar 0,547 . Artinya pengaruh terhadap kinerja personil ini yang paling terbesar dibandingkan dengan variabel bebas lainnya. Sehingga ini menjadi fokus dalam kebijakan instansi untuk mengoptimalkan kinerja personil.

3. Dari persamaan regresi terlihat bahwa niai yang terbesar ke-2 adalah motivasi dengan skor sebesar 0,487. Artinya pengaruh terhadap kinerja personil ini yang paling besar dibandingkan dengan variabel bebas lainnya. Sehingga ini menjadi fokus dalam kebijakan ke-2 instansi untuk mengoptimalkan kinerja personil.

4. Dari persamaan regresi terlihat bahwa niai yang terbesar ke-3 adalah lingkungan kerja dengan skor sebesar 0,278. Artinya pengaruh terhadap kinerja karyawan ini yang terendah dibandingkan dengan variabel bebas lainnya. Sehingga ini menjadi fokus dalam kebijakan dalam pemilihan terakhir untuk dijalankan instansi untuk mengoptimalkan kinerja personil.

\section{KESIMPULAN DAN SARAN}

Kesimpulan dari hasil penelitian tentang pengaruh disiplin, motivasi dan lingkungan kerja terhadap kinerja personil Polress Metro Bekasi Kota adalah sebagai berikut: 1) Terdapat pengaruh positif dan signifikan disiplin kerja 
terhadap kinerja personil Satuan Reskrim di Polres Metro Bekasi Kota, 2) Terdapat pengaruh positif dan signifikan motivasi kerja terhadap kinerja personil Satuan Reskrim di Polres Metro Bekasi Kota. 2) Terdapat pengaruh positif dan signifikan lingkungan kerja terhadap kinerja personil Satuan Reskrim di Polres Metro Bekasi Kota. 3) Terdapat pengaruh positif dan signifikan disiplin kerja, motivasi kerja dan lingkungan kerja secara bersamasama terhadap kinerja personil Satuan Reskrim di Polres Metro Bekasi Kota. Dengan demikian dapat disimpulkan bahwa apabila kinerja ingin meningkatkan instansi harus meningkatkan disiplin, motivasi dan lingkungan kerja.

\section{SARAN}

Berdasarkan kesimpulan yang telah dikemukakan di atas, berikut adalah saran yang dapat diberikan, yaitu: 1) Penerapan disiplin kerja personil Satuan Reskrim Polres Metro Bekasi Kota harus dipertahankan disarankan pemberian surat peringatan bisa menjadi pilihan untuk memberi teguran kepada personil yang tidak disiplin/ tidak tepat waktu dalam menyelesaikan pekerjaan agar personil memiliki tanggung jawab penuh pada pekerjaan yang diberikan. 2) Memberi penghargaan kepada personil yang loyal terhadap instansi. Pemberian penghargaan dapat diberikan apa bila personil dapat menyelesaikan pekerjaan sesuai target yang ditentukan. Penerapan pengembangan karir juga harus diperhatikan instansi, penerapan pengembangan karir pada personil yang berprestasi dan loyal dapat memberi personil harapan sehingga bersemangat dan berkompetisi untuk bekerja maksimal dan mendapatkan jabatan yang lebih baik. 3) Instansi perlu menciptakan lingkungan keja yang baik seperti meningkatkan kebersihan dengan memberikan reward terhadap ruangan yang terbersih agar para personil selalu menjaga kebersihan, fasilitas kerja yang mendukung, keselamatan dalam bekerja serta hubungan yang baik antar rekan sejawat, pimpinan dan bawahan sehingga dalam melaksanakan tugas merasa tenang dan nyaman sehingga pencapaian kinerja lebih optimal. 4) Bagi peneliti yang tertarik melakukan penelitian sejenis diharapkan untuk mengobservasi dan mengeksplorasi lebih jauh mengenai permasalahan-permasalahan yang terdapat pada Satuan Reskrim di Polres Metro Bekasi Kota pada khususnya dan objek lain pada umumnya dengan menambahkan variabel lain seperti pengembangan karir, kompetensi, pelatihan dan gaya kepemimpinansehingga peneliti dapat mengetahui faktor-faktor apa saja yang berpengaruh terhadap kinerja pegawai, selain itu juga disarankan untuk tetap menggunakan metode kuantitatif dalam mendapatkan data dan informasi yang lebih akurat. 


\section{DAFTAR PUSTAKA}

Azwar.(2012). Sikap Manusia: Teori dan Pengukurannya. Pustaka Pelajar. Yogyakarta.

Dwiyanto, Agus. (2014). Mewujudkan Good Governanve melalui Pelayanan Publik. Gadjah Mada University Press. Semarang.

Hasibuan, SP Malayu. (2012). Manajemen Sumber Daya Manusia. PT. Bumi Aksara. Jakarta.

Kadarmanta, A. (2007). Membangun Kultur Kepolisian. PT. Forum Media Utama. Jakarta.

Nitisemito, Alex S. (2012). Manajemen Suatu Dasar dan Pengantar. Arena IImu. Jakarta.

Pasolong, Harbani. (2013). Kepemimpinan Birokrasi. CV. Alfabeta. Bandung.

Peraturan Republik Indonesia Nomor 2 Tahun 2003 tentang Peraturan Disiplin Anggota Republik Indonesia.

Prawirosentono, S. (2013). Manajemen Sumber Daya Manusia, Kebijakan Kinerja Karyawan. BPFE. Yogyakarta.

Rahardi, Pudi. (2013). Profesionalisme dan Reformasi Polri. Laksbang Mediatama. Surabaya.

Sedarmayanti. (2013). Sumber Daya Manusia dan Produktivitas Kerja. CV Mandar Maju. Bandung.

Siagian, Sondang P. (2014). Manajemen Sumber Daya Manusia. PT. Bumi Aksara. Jakarta.

Sinambela, Lijan Poltak. (2012). Kinerja Pegawai. Graha llmu. Yogyakarta.

Tjiptogoro, Iffah. (2017), Analysis of Strategic Factors of Human Resources Management for Corruption Prevention. Volume 15, Number 6, 2017. International Journal of Applied Business and Economic Research. Serial Publications Pvt. Ltd. 
Tjiptogoro, Iffah. (2017), Performance Improvement Through Human Capital Stategic For Civil Sevant. Volume 24, Number 6, 2017. International Journal of Applied Business and Economic Research. Serial Publications Pvt. Ltd.

Tjiptogoro, Iffah, Fransica, Hapzi. (2017), Corruption Prevention and Deterrence Through Strategic Human Resources Management Vol: 6, Issue 1, January 2017. International Journal of Application or Innovation in Engineering \& Management. IJAIEM Index by Thomson Reuter \& Other.

Tjutju Yuniarsih dan Suwatno, (2008). Manajemen Sumber Daya Manusia Teori

Tjiptogoro, Djumarno. (2018), The Strategic Role of Management of Human Resources to Prevent Corruption.Vol 3, Number 3, 2018. Journal of Business and Economics Review. Global Academy of Training \& Research (GATR) Enterprice.

Tjutju Yuniarsih dan Suwatno, (2008). Manajemen Sumber Daya Manusia Teori Aplikasi dan Isu Penelitian. Alfabeta. Bandung.

Walton. (1999). Strategic Human Resource Development. Pearson Education Limited. Edinburgh Gate Harlow. England.

Werther and Davis. (2006). Human Resources and Personal Management. International Edition. Mc Graw Hill. Print in Singapure.

Wheelen and Hunger. (2006). Strategic Management and Business Policy. Pearson Education International. United State of America 